УДК 355.422:356.169

DOI: 10.33099/2707-1383-2021-40-2-143-153

\title{
Ігор Данилюк
}

кандидат військових наук, дочуент,

начальник кафедри

Десантно-итурмових військ

і Сил спеціальних операцій,

Національний університет оборони Украйни

імені Івана Черняховського

(Київ, Україна)

ORCID: https://orcid.org/0000-0002-0677-7051

Електронна пошта: danil38@i.ua

\section{Володимир Наумов}

науковий співробітник

науково-дослідної лабораторії кафедри

Десантно-итурмових військ

і Сил спеціальних операцій,

Національний університет оборони Украӥни

імені Івана Черняховського

(Київ, Украӥна)

ORCID: https://orcid.org/0000-0002-2944-2994

Електронна nowma:vegerhel@gmal.com

\section{БОЙОВІ ДІЇ УГРУПУВАННЯ ВИСОКОМОБІЛЬНИХ ФОРМУВАНЬ ЗБРОЙНИХ СИЛ США В ОПЕРАЦЇ̈ \\ БАГАТОНАЦІОНАЛЬНИХ СИЛ «БУРЯ В ПУСТЕЛІ» (1991 РІК) - ЯК ПРИНЦИПОВО НОВИЙ ВАРІАНТ ЗАСТОСУВАННЯ ВИСОКОМОБІЛЬНИХ ФОРМУВАНЬ В ОПЕРАЦІЯХ}

В статті на матеріалах опублікованих джерел проаналізовано досвід бойових дій угруповання високомобільних формувань збройних сил США в операиії «Буря в пустелі». Історичний досвід застосування, яких свідчить, щуо їх дії є найважливішою складовою операцій. Змінюються засоби збройної боротьби, розвиваються способи дій, розширюється коло завдань, які виконуються високомобільними формуваннями.

Виявлено і досліджено, щзо в зазначеній операчії був започаткований принципово новий варіант застосування циих формувань в операціях, 
а саме перенесені акценти їх застосування з наземного компоненту на повітряний і тим самим обраний найбільш раџіональний спосіб застосування аеромобільного з'єднання.

Ключові слова: армійська авіація, десантно-штурмові дії, з'єднання, підрозділ, тактика.

Постановка проблеми. Вивчення історичного досвіду бойового застосування угруповання високомобільних формувань збройних сил США в операції Багатонаціональних Сил «Буря в пустелі» має практичне значення для боєздатності Збройних Сил України в сучасних умовах.

Аналіз досліджень та публікацій. Окремі аспекти вирішення порушеної проблеми в своїх наукових працях розглядали провідні військові дослідники: Robert H. Scaleys (Robert, H. Scaleys. 1994), Atkinson Rick (Atkinson, Rick. 1994), С. Я. Лавренов та И. М. Попов (Лавренов, С. Я. \& Попов, И. М. 2003); А. И. Михайлов (Михайлов, А. И. 2004), А. И. Калистратов (Калистратов, А. И. 2014).

Мета статті полягає у вивченні, аналізі та узагальненні досвіду тактики дій угруповання високомобільних формувань збройних сил США в операції Багатонаціональних Сил «Буря в пустелі». Досягнення мети передбачає вирішення наступних завдань: з'ясувати стан наукової розробленості теми; розкрити процес підготовки та проведення операції; оцінити ефективність дій ви- сокомобільних формувань збройних сил США в операціях.

Виклад основного матеріалу дослідження. Після вторгнення іракських військ в Кувейт, в зону Перської затоки для захисту Саудівської Аравії і країн Затоки від можливого продовження іракської агресії були перекинуті частини Багатонаціональні Сил. Командуванням збройних сил США був розроблений план операції щодо розгрому іракських збройних сил і звільнення Кувейту, основою якого була концепція «повітряно-наземної операції». Операцію передбачалося провести в два етапи.

На першому етапі в ході проведення повітряної наступальної операції планувалося: завдати масованих ударів по ключових об'єктах і військам на території Іраку і Кувейту; подавити систему протиповітряної оборони збройних сил Іраку; завоювати повне панування в повітрі шляхом виведення з ладу систем ППО (радарів, пускових установок, аеродромів); дезорганізувати систему державного і військового управління; вивести 3 ладу до 50\% особового складу i техніки іракського угрупування, що займало оборонні позиції вздовж кордону з Саудівською Аравією. 
На другому етапі, в ході «повітряно-наземної операції», передбачалося силами сухопутних військ і морської піхоти здійснити обхід головного угруповання іракських військ з одночасною висадкою в тил чисельних оперативних і тактичних десантів оточити і знищити по частинах угруповання іракських збройних сил в Кувейті та на півдні Іраку.

Авіацією Багатонаціональних Сил було завдано ряд масованих авіаційних ударів по важливим об'єктам на всій території Іраку. В результаті, було завойовано і впевнено утримувалося панування в повітрі. У тий же час система управління збройними силами Іраку продовжувала функціонувати, а іракська авіація понесла лише незначні втрати. Умови для успішного проведення повітряно-наземної операції зі звільнення Кувейту були створені, але не на достатньму рівні (Atkinson, Rick 1994, p. 17-18).

На основі оцінювання угруповання іракських військ було прийнято рішення щодо створення зовнішнього і внутрішнього фронтів оточення. VII-й корпус 3С США отримав наказ наступати в напрямку м. Хафар-Ель, м. Батин, м. Басра та розгромити іракські війська в районі м. Ез-Зубейр і замкнути фронт оточення військ IIIго армійського корпусу Іраку в Кувейті.

XVIII-му повітряно-десантному корпусу США було поставлене завдання наступати на Еш-Шуба, Ель-Бусайя, Ен-Насирія і у взаємо- дії з VII-м корпусом США подолати оборону іракських військ та знищити корпусні резерви противника в районах м. Джада, м. Ель-Бусайя, і перерізати шосе Басра-Багдад в районі м. Ен-Насирія, тим самим завершити створення зовнішнього фронту оточення південного угрупування іракських військ. Під час планування наступу, командування коаліції визначило військам арабських союзників і американській морській піхоті роль «ковадла», що скує III-й і VII-й іракські корпуси в Кувейті. Британські та американські бронетанкові i механізовані бригади мали охопити іракські війська в Кувейті з лівого флангу, завдаючи при цьому удар по іракській республіканській гвардії, що була розташована в районі Басри і тим самим виконати роль «молота».

Для прикриття лівого флангу головного угруповання на базі 6-ї танкової бригади Франції було створено оперативно-тактичне угруповання, до складу якої булла включена бригада 82-ї повітряно-десантної дивізії США. За дві доби до початку військових дій ця група мала приховано перекину та в район м. Рафха і розгорнулася уздовж саудівсько-іракського кордону. Її завдання полягало в стрімкому наступі в напрямку Ес-Сальман, Самава та оволодінні рубежем річки Євфрат (Калистратов, А. И. 2014, с. 27-29).

У процесі проведеної Багатонаціональними Силами «повітряно-наземної наступальної операції» «Буря 
в пустелі» 101-я пшд успішно здійснила оперативний аеромобільний рейд, ефективно вирішивши в оперативному тилу противника низку оперативних завдань в смузі 360 км по фронту і 180 км в глибину.

Зміст рейду полягав у стрімкому переміщенні вертольотних бригад дивізії стрибками по 50-80 км з одного, попередньо захопленого з повітря і обладнаного піхотними аеромобільними бригадами в тилу противника передового району базування вертольотів, в інший. Спираючись на ці райони, вертольотні бригади мали наносили вогневі удари по оперативним резервам противника, що висувався в район ведення бойових дій, знищували об'єкти його тилу і порушували комунікації, висаджували повітряні десанти для захоплення i утримання окремих ключових районів і об'єктів (Atkinson, Rick. 1994, p. 93-96).

За змістом аеромобільний рейд уявляв послідовне багаторазове висадження в оперативно-тактичній глибині противника підрозділів ударних вертольотів. Але це були не повітряні десанти. Тут все було навпаки: заздалегідь висаджені аеромобільні піхотні підрозділи захоплювали райони місцевості і в подальшому забезпечували посадку та функціонування підрозділів, частин ударних вертольотів. Ударні вертольоти спроможні при груповому застосуванні повністю паралізувати роботу оперативного тилу противника і зір- вати перегрупування його резервів (Калистратов, А. И. 2014, с. 77-78). Для забезпечення виконання окремих завдань вертольотами з'єднання, висаджувалися повітряні десанти у складі піхотних аеромобільних частин і підрозділів.

3 початком наземного етапу операції, війська Багатонаціональних Сил здійснили прихований маневр на північ і завдали потужного удару по флангу іракської армії в Кувейті. Наступ був проведений за трьома напрямками. На приморському фланзі наступали 1-a i 2-а дивізії морської піхоти США, піхотні і танкові дивізії Саудівської Армії, Сгипту, Кувейту і Сирії. На центральній ділянці фронту удар наносили бронетанкові дивізії VII-го корпусу ЗС США та 1-а англійська бронетанкова дивізія. У резерві залишився XVIII-й повітрянодесантний корпус США. Він мав наступати на крайньому західному фланзі і вийти до р. Свфрат (Калистратов, А. И. 2014, с. 92-94). Американські, англійські і французькі війська пройшли по іракській території на схід від кувейтського кордону і вийшли в тил частинам республіканської гвардії.

3 початком атаки і зайняттям піхотною дивізією визначеного району iз завданням встановлення контролю над долиною річки 3-тя бригада 101-ї пшд була десантована на південному березі р. Свфрат на захід від м. Ан-Насіння. 101-я пшд XVIII-й повітрянодесантного корпусу, 24-а 
механізована дивізія у взаємодії 3-м окремим бронекавалерійським полком здійснила глибокий маневр з метою оточення кувейтського угруповання іракських військ.

Головним завданням угруповання було перехоплення i блокування стратегічно важливого шосе № 8 м. Ассам - м. Басра і тим самим зірвати підхід оперативних та тактичних резервів противника з району м. Басpa.

На першому етапі рейду з ранку першого дня наступу передовий загін дивізії був перекинутий повітрям через незайняті іракськими військами проміжки між з'єднаннями та захопив і пополудні обладнав передову операційну базу «Кобра» (далі-ПОБ) в 80 км від лінії зіткнення сторін.

ПОБ мала форму кола з діаметром близько 15 км. Перекидання передового загону було здійснено 66 вертольотами UH-60 і 30 CH-47 (понад 500 чоловік піхоти і артилерійський дивізіон 105-мм гаубиць).

В подальшому він був посилений 1500 піхотинцями, 50 БМ ПТКР, дивізіоном 105-мм гаубиць 1-ї (паембр), яких висадила вертольотна група у складі 100 CH-47. Бойові вертольоти з бази «Кобра» вже в перший день нанесли вогневе ураження по колонам противника, що пересувався по шоce № 8 .

3 ранку другого дня на базу «Кобра», обійшовши вузли опору іракських військ, прибув наземний конвой з запасами пального і боєприпасів в складі 700 вантажівок, 2000 чоловік особового складу та 30 БМ ПТУР, що дозволило різко підвищити інтенсивність застосування бойових вертольотів (Лавренов, С. Я. \& Попов, И. М. 2003, c. 213-229).

В ході другого етапу рейду через 30 годин 3 моменту початку наступу було перерізано найважливішу комунікацію, а саме шосе № 8, яка живила все кувейтське угруповання іракських військ. Відстань шосе № 8 км від переднього краю оборони противника становить 200 км.

Із завданням заборони своєчасного висування (маневру) резервів противника, постачання матеріальних засобів в район ведення бойових дій в ході контрудару своїх військ 25 лютого 1991 року о 12.16 в 40 км на південь від шосе з 30 вертольотів СН-47 був висаджений повітряний десант у складі трьох протитанкових рот на БМ ПТКР «Тоу», які перехопивши шосе, о 15.08 забезпечили висадку прямо на нього піхотного аеромобільного батальйону.

В подальшому туди ж була перекинута 3-тя паембр, яка за підтримки бойових вертольотів з ПОБ «Кобра» і контролювала шосе до кінця операціï.

3 ранку цього ж дня із завданням щодо оволодіння рубежем, 3 метою створення вигідних умов для розвитку наступу VII-й АК США, на глибину до 70 км була десантована 2-га паембр. Вона захопила вузол доріг 
в районі м. Рахав із завданням зриву відходу іракських частин в напрямку м. Басра.

Десантуванню передувала ретельна розвідка і рекогносцировка району висадки спеціальними групами зі складу 1-го батальйону 327-го піхотного полку 101 пшд. Висадку та бойові дії бригади забезпечували до 300 вертольотів різного призначення, в тому числі понад 50 бойових.

На третьому етапі рейду вживалися заходи щодо зриву спроби відходу за р. Свфрат великого угруповання противника з району м. Басра.

3 цією метою в першій половині 27 лютого силами перекинутої вертольотами 2-ї паембр в район південніше м. Джалібах, що приблизно в 100 км від м. Басра і в 5060 км від лінії бойового зіткнення та ПОБ «Кобра», була обладнана та забезпечена достатньою кількістю пального i боєприпасів нова ПОБ «Гадюка». Друга половина дня була присвячена перебазуванню в цю ПОБ 101-ї і 12-ї бригад армійської авіації, підготовці їх до бойового застосування і нанесення силами 64 бойових вертольотів АН-64 серії глибоких вогневих ударів по противнику, що відходив (Михайлов, А. И. 2004, с. 56-58).

Порядок нанесення глибокого групового удару бойовими вертольотами (на глибину 50-70 км від лінії зіткнення військ) ілюструє удар 11-ї бригади армійської авіації 7 АК (США), що був нанесений в ніч на
27 лютого 1991 року спільно з винищувачами-бомбардувальниками FB111.

Удар наносився по 10-й танковій дивізії і танкової дивізії «Хаммурапі» іракців, які намагалися вирватися 3 кільця оточення.

Порядок виконання завдання під час нанесення удару включав: переліт вертольотів в передовій вихідний район «Скіп»; «розчищення» маршруту прольоту від засобів ППО противника 6-ма бойовими вертольотами, переліт через лінію зіткнення сторін і вихід в пункт розходження, одночасна атака колон противника, що здійнювали відхід, трьома ротами бойових вертольотів із застосуванням ПТКР «Хеллфайер», повернення, підготовка і здійснення другого вильоту.

Дальність застосування ПТКР (до 8 км) дозволяла не входити в зону ефективного вогню засобів ППО військ, що відходили, а тактична авіація працювала паралельно в своїй смузі кожні 20 хвилин парами літаків, озброєних чотирма керованими авіабомбами кожен.

Результатом удару стало ураження більше сотні бронемашин противника, що відходив (Лавренов, С. Я. \& Попов, И. М. 2003, с. 241-245). Звичайно, успіх аеромобільного рейду 101-ї пшд багато в чому був забезпечений багаторазовою якісною перевагою Багатонаціональних Сил, що дозволив 3 самого початку захопити і утримувати до кінця операції пану- 
вання в повітрі як головну умову переваги.

Успіху рейду також сприяли слабка протидія ППО іракців, повна відсутність аеромобільних формувань в районі бойових дій і достатня кількості бойових вертольотів. Мотопіхотні, танкові з'єднання і частини виявилися нездатними адекватно реагувати на стрімкі переміщення аеромобільних підрозділів навіть у пустельній місцевості, прохідність якої і умови видимості були майже ідеальними.

Все це свідчить про те, що сучасна збройна боротьба неможлива без широкомасштабного застосування високомобільних десантних формувань для ведення повітряно-наземних дій. Перевага в повітрі і в аеромобільності дає можливість в найкоротші терміни здобувати перемоги при низьких втратах своїх військ в ході ведення наступу та адекватно реагувати на спроби аеромобільного проникнення противника в тактичний і оперативний тил під час відбиття його ударів в ході оборонних дій.

Наявність достатньої кількості сил і засобів армійської авіації та аеромобільних формувань в складі об’єднань не тільки різко підвищує їх оперативну мобільність і здатність здійснення глибокого маневру в тил противника та дозволяє контролювати великий незайнятий військами простір, а також надає їм принципово нову якість контраеромобільності.

Ця якість дає можливість швидко i ефективно зривати висадку пові- тряних десантів і блокувати спроби здійснення протиборчої стороною оперативного аеромобільного рейду.

3 цією метою в складі оперативного об'єднання сухопутних військ доцільно мати ударну і багатоцільову вертолітні бригади, а також десантно-штурмову бригаду (три-чотири десантно-штурмових батальйони, один-два дивізіони 122-мм гаубиць, протитанковий дивізіон ПТКР на БМ і вертольотну групу у складі бригади).

Порядок дій аеромобільного компонента в першому випадку включав:

маневр повітрям частини сил 3 метою захоплення і обладнання на шляху противника, що прорвався або обходить наш фланг, передового району базування (далі - ПРБ) вертольотів; переліт в цей район вертолітних формувань з запасами матеріальних засобів і нанесення групових ударів по противнику; висадка піхотних аеромобільних батальйонів на напрямках просування військ противника 3 метою їх сковування і ведення стримуючих дій за підтримки ударних вертольотів до підходу наземних сил.

Подібний алгоритм дій в ході операції неодноразово повторювався за методом дій «пожежної команди».

У другому випадку застосування аеромобільного з'єднання здійснювалося у формі контраеромобільного рейду.

При цьому підрозділи з'єднання стрибками переміщується 3 одно- 
го ПРБ в інший з метою знищення передових операційних баз аеромобільних формувань противника, і особливо вертольотів, в тому числі і в польоті, як на своїй території, так і над територією противника.

Висаджені противником повітряні десанти оперативно блокуються перекинутими повітрям аеромобільними батальйонами, потім за підтримки ударних вертольотів знищуються спільно з наземними військами, що підходять. Незайняті військами проміжки між з'єднаннями першого ешелону і відкриті фланги патрулюються вертольотами і контролюються висадженими $з$ вертольотів наземними спостережними постами. При виникненні загрози прориву противника вона ліквідується за допомогою маневру головних сил аеромобільного з'єднання. При певних обставинах можливо і здійснення глибокого аеромобільного оперативного рейду по тилах ударних угруповань військ противника.

Під час проведення наступальних операцій, застосування аеромобільних з'єднань 3 метою здійснення оперативного рейду в інтересах розвитку успіху та створення в глибині побудови противника активно діючого фронту або глибокого обходу його флангів при сприятливих умовах цілком можливо.

В ході оборонних операцій аеромобільний компонент наших об'єднань може застосовуватися: як аеромобільний резерв для вирі- шення в різних районах зони відповідальності об'єднання (смуги оборони) кризових ситуацій; в якості основного контраеромобільного елемента, який здатний зірвати маневр в наш тил і дії в ньому аеромобільних формувань противника, a також оперативно блокуватийого повітряні десанти, що висаджені; для здійснення контролю над незайнятими військами просторами; для здійснення глибокого оперативного рейду по тилах ударних угруповань ворога.

При цьому бойові вертольоти можуть надати суттєву допомогу рейдовому загону або мобільному резерву загальновійськового формування армії, що діє в глибині побудови противника.

В даному випадку ефективність вогневої підтримки значно підвищується. Так було під час бою діючій у відриві від основних сил 1-ї бригади 24-ї механізованої дивізії армії США 24 березня 1991 року з іракською дивізією «Хаммурапі», що здійснювала відхід. По колонах противника було завдано удару 18-ма бойовими вертольотами АН-64 «Апач» 1-го батальйону 24-го протитанкового вертолітного полку дивізійної бригади армійської авіації. Вертольоти випустили 107 ПТУР «Хеллфайер», які знищили 102 бойові броньовані машини. При цьому авіація не понесла жодних втрат, так як в зону дійсного вогню, що прикривали колону засоби протиповітряної оборони 
(ЗРК «Стріла-1», «Стріла-2», ЗСУ23-4 «Шилка») не входила. Бій був завершений фланговим маневром батальйону танків «Абрамс» (4-й батальйон 64-го танкового полку) і знищенням залишків колони. Результат бою: знищено 185 бойових броньованих машин і 400 вантажівок, пошкоджено 34 артилерійських систем (Robert, H. Scaleys 1994, c. 256-260, 276-278).

Висновки дослідження. Таким чином, в операції «Буря в пустелі» був започаткований принципово новий варіант застосування високомобільних формувань в операціях, а саме аеромобільний рейд, досвід якого значно збагатив теорію застосування аеромобільних формувань. Високий ступінь ефективності використання бойового потенціалу повітряного компоненту аеромобільного з'єднання в оперативному тилу противника за умов забезпечення його дій наземним компонентом дає змогу перенести акценти застосування високомобільного формування з наземного компоненту на повітряний і тим самим обрати найбільш раціональний спосіб застосування аеромобільного формування, що є суттєвим рушієм розвитку теорії застосування високомобільних формувань в операціях.

\section{СПИСОК ВИКОРИСТАНИХ ДЖЕРЕЛ І ЛІТЕРАТУРИ}

Atkinson, Rick (1994). Crusade: The Untold Story of the Persian Gulf War. Houghton Mifflin Harcourt, 186 p.

Калистратов, А. И. (2014). Аэромобильный рейд. Армейский сборник. № 11, 192 с.

Лавренов, С. Я. \& Попов, И. М. (2003). «Буря в пустыне» над Персидским заливом. Советский Союз в локальных войнах и конфликтах. М.: Астрель, 314 с.

Михайлов, А. И. (2004). Иракский капкан. Москва: «Яуза», 232 с.

Robert, H. Scaleys (1994).Certain Victory: The US Army in the Gulf War. Fort Leavenworth. Kansas, 290 p.

\section{REFERENCES}

Atkinson, Rick (1994). Crusade: The Untold Story of the Persian Gulf War. Houghton Mifflin Harcourt, 186 p. [in English].

Kalystratov, A. I. (2014). Aeromobilnyi reyd [Airmobile raid]. Armiyskyi zbirnyk. № 11, 192 s. [in Russian ].

Lavrenov, S. Y. \& Popov, Y. M. (2003). "Burya v pusteli” nad Perskoyu zatokoyu [“Desert Storm" over the Persian Gulf]. Sovetskiy Soyuz v lokalnyih voynah i konfliktah. M.: Astrel, 314 s. [in Russian]. 
Mikhaylov, A. I. (2004). Irakskyy kapkan [Iraqi trap]. Moskva: "Yauza", 232 s. [in Russian].

Robert, H. Scaleys (1994). Certain Victory: The US Army in the Gulf War. Fort Leavenworth, Kansas, 290 s. [in English].

\section{Ihor Danyliuk}

PhD, Associate Professor,

Head of the Airborne Assault Troops and Special Operations Forces Department,

The National Defence University of Ukraine named after Ivan Cherniakhovskyi

(Kyiv, Ukraine)

ORCID: https://orcid.org/0000-0002-0677-7051

\section{Volodymyr Naumov}

Research Scientist of the research laboratory of the Airborne Assault Troops and Special Operations Forces Department, The National Defence University of Ukraine named after Ivan Cherniakhovskyi (Kyiv, Ukraine)

ORCID: https://orcid.org/0000-0002-2944-2994

\section{COMBAT OPERATIONS OF A GROUPING OF THE US ARMED FORCES HIGHLY MOBILE FORMATIONS IN THE OPERATION OF A MULTINATIONAL FORCE "DESERT STORM" (1991) - AS A FUNDAMENTALLY NEW OPTION FOR THE USE OF HIGHLY MOBILE FORMATIONS IN OPERATIONS}

Combat operations of the US armed forces highly mobile formations grouping in the multinational forces "Desert Storm" operation (1991) are discussed in the article. In modern conditions, there remains a need to study the experience of using highly mobile formations of the leading NATO member states in modern military conflicts.

The entire historical experience of using airborne assault forces indicated that they were the most important component of the battle (operation). The means of warfare are changing, methods of action are developing, and the range of missions performed by airborne assault forces is expanding. 
The fundamentally new version of the use of highly mobile formations in operations was founded in "Desert Storm" operation, and namely, the airmobile raid, the experience of which significantly enriched the theory of using airmobile formations. The high level of efficiency in the use of the combat potential of airmobile unit airborne component in the operational rear of the enemy, provided that its actions are ensured by the ground - based element, makes it possible to shift the emphasis of the use of the highly mobile formation along the ground component to the air one, thereby choosing the most rational method of using the airmobile formation, which is an essential stimulus for the application highly mobile formations theory development in operations.

The consideration of this episode of the highly mobile formations participation in the military conflicts of our time, their analysis, and conclusions made it possible to assert that.

The emphasis in the development of the theory of the use of the airborne assault forces of the Ukrainian Armed Forces should be made on the use of the combat potential of the air component, namely on the Army aviation unit of the Land Forces as the main component of a highly mobile formation, the basis of the combat power of the airborne assault formation, while the method for performing tasks behind the enemy lines with airborne assault (after parachuting units) remains relevant.

Keywords: army aircraft, airborne assault, army unit, military unit, tactics. 